\title{
Fruit and seed exploitation by small rodents of the Brazilian Atlantic forest
}

\author{
E.M. VIEIRA \\ $P G$ - Ecologia. Universidade Estadual de Campinas, Campinas, SP Brazil \\ Current address: Laboratório de Ecologia de Mamíferos, \\ Centro de Ciências da Saúde - UNISINOS. CP 275. São Leopoldo, RS. 93022-000 Brazil \\ E-mail : vieira@cirrus.unisinos.br
}

M.A. PIZO
PG - Ecologia. Universidade Estadual de Campinas, Campinas, SP Brazil
Current address: Departamento de Botânica,
Universidade Estadual Paulista, 13506-900 Rio Claro, SP, Brazil

P. IZAR

Dept. de Ecologia Geral, Universidade de São Paulo, São Paulo, SP, Brazil

KEY WORDS

fruits, seeds, exploitation, rodents, Brazilian Atlantic forest.

\section{SUMMARY}

In the Brazilian Atlantic forest (BAF) there are at least 57 rodent species and most of them are considered omnivorous. These species feed, more or less frequently, on fruits and seeds. Nevertheless the potential role of each species as frugivorous, seed predator or seed disperser is still unclear. In the present study we analyzed patterns of fruit and seed exploitation by eight small rodent species from an Atlantic Forest site. We offered to captive animals fruits of 30 plant species ( 23 genera, 15 families). After $48 \mathrm{~h}$ we recorded consumption patterns of pulp/aril and seed. Rodent species differed in their patterns of fruit and seed exploitation. The smallest species, Akodon serrensis, Oligoryzomys nigripes, and Wilfredomys pictipes_(body size range : 26-45 g), and also the medium-sized Oecomys aff. concolor (84 g) fed mainly on pulp and also on small to medium-sized seeds ( $<10 \mathrm{~mm}$ diameter). The medium-sized rodent, Oryzomys russatus $(91 \mathrm{~g}$ ) fed on pulp and also on seeds with diameter $\leq 15$ $\mathrm{mm}$. Thus larger seeds remain intact after being manipulated by such species. The medium-sized Delomys dorsalis $(72 \mathrm{~g})$ and the larger Trinomys iheringi $(274 \mathrm{~g}$ ) and Nectomys squamipes (253 g) form a third group, which consumed both fruit and seed of most species independent of their size. These later two species and also O. russatus are probably the main seed predators in the rodent community of the BAF. 


\begin{abstract}
RÉSUMÉ
Dans la Forêt Atlantique Brésilienne (FAB) il y a aux moins 57 espèces de rongeurs dont la plupart sont omnivores. Ces espèces consomment fréquemment des fruits et des graines. Cependant, le rôle de ces rongeurs, comme frugivores ou granivores ou disséminateurs de graines est assez mal connu. Dans cette étude, leur importance dans l'exploitation des fruits et des graines a été évaluée pour huit espèces de rongeurs capturés dans le domaine de la Forêt Atlantique. Les fruits et graines de 30 espèces végétales ( 23 genres, 15 familles) ont été offerts à ces rongeurs maintenus en captivité. Après 48 heures les données concernant le paramètre d'exploitation des fruits et semences a été évalué pour ouit espèces de petits rongeurs capturés dans le domaine de la Forêt Atlantique. Les fruits de 30 espèces végétales ont été offerts aux animaux maintenus confinés ( 23 genres, 15 familles). Après 48 heures les données concernant la consommation de pulpe ou arille ont été observées. Selon les espèces on constate des différences dans l'exploitation des fruits et des graines. Les plus petits rongeurs Akodon serrensis, Oryzomys nigripes et Wilfredomys pictipes (26$45 \mathrm{~g}$ ), Oecomys aff. Concolor (84 g) qui est de taille moyenne, ont consommé surtout de la pulpe, et aussi des graines petites et moyennes $(<10 \mathrm{~mm}$ de diamètre) ; Oryzomys russatus (91 g), rongeur de taille moyenne, s'est nourri de pulpe ainsi que de graines ayant jusqu’à $15 \mathrm{~mm}$ de diamètre; les graines plus grandes comme celles de Cryptocarya moschata (lauraceae), Eugenia melanogyna et E. stictosepala (myrtacea) sont restées intactes après qu'il les ait manipulées. Un autre rongeur de taille moyenne Delomys dorsalis (72 g) ainsi que Trinomys iheringi $(274 \mathrm{~g}$ ) et Nectomys squamipes (253 g) de grande taille, ont constitué un troisième groupe qui a consommé autant de pulpe que des graines de la plupart des espèces, quelle que soit leur taille. Il est fort possible que les deux dernières espèces ainsi qu'O. russatus soient les principaux rongeurs granivores de la Forêt Atlantique Brésilienne.
\end{abstract}

\section{INTRODUCTION}

Rodents are the most abundant mammals of Neotropical forests (Glanz 1990), which may harbor from 11 to 20 species in a given locality (Voss and Emmons 1996). Most of them are omnivorous or frugivorous-omnivorous, which means that they feed more or less frequently on fruits and seeds (Emmons and Feer 1997). Because of their diet and abundance in Neotropical forests these animals affect seed placement and survival, thus influencing plant species distributions and community structure (Janzen 1970; Howe and Smallwood 1982; Hallwachs 1986; Terborgh 1986; Smythe 1989 ; Brewer and Rejmánek 1999).
The role of rodents as frugivores, seed predators, and seed dispersers of Neotropical plant species has been investigated focusing chiefly on large species (mainly Dasyproctidae). Nevertheless, several authors have noted the potential importance of small rodents as frugivores and seed dispersers in the Neotropics (e.g. Forget 1991 ; Sánchez-Cordero and Martínez-Gallardo 1998 ; Brewer and Rejmánek 1999). Probably because of their size and nocturnal habits, the actual role of individual small rodent species as dispersers and seed predators is largely unknown and most available information is anecdotal. Published studies generally concern to overall rates of seed removal or seed predation by frugivorous mammals in 
general (e. g. Forget 1992) or to mammals in certain size classes without reference to specific taxa (e. g. Terborgh et al. 1993). Exceptions to this lack of detailed studies on small rodent and seed interactions are works conducted by Adler (1995) and Hoch and Adler (1997) with the echimyid Proechimys semispinosus in Central America, Guillotin (1982) with Proechimys cuvieri and Oryzomys capito in French Guyana, and the study of Brewer and Rejmánek (1999) analyzing the role of Heteromys desmarestianus on seed fates in a Neotropical forest.

This lack of knowledge on frugivory and seed predation by species of small rodents extends to the Brazilian Atlantic forest (BAF). This highly threatened forest still harbors a high mammalian diversity including at least 57 rodent species, most of them considered omnivorous (Emmons and Feer 1997). In the present study we report on patterns of fruit and seed exploitation by eight captive rodent species of the Atlantic forest. We were particularly interested in seed exploitation by rodents, so we discuss our results within the context of seed selection and its implications for seed predation.

\section{METHODS}

We captured rodents in forested areas of the Parque Estadual Intervales (PEI), an Atlantic Forest reserve of approximately $490 \mathrm{~km}$ ? located in southern São Paulo state, southeastern Brazil $\left(24^{\circ} 12^{\prime}\right.$ to $24^{\circ} 25^{\prime} \mathrm{S}$; $48^{\circ} 03^{\prime}$ to $\left.48^{\circ} 30^{\prime} \mathrm{W}\right)$. This reserve has an altitudinal range from 70 to $1,100 \mathrm{~m}$., and together with 3 other parks, forms a continuous protected area of more than 1,200 $\mathrm{km}$ ?. A detailed description of the vegetation of the area can be found in Vieira and Izar (1999).

The rich rodent community of the PEI is representative of the Atlantic forest, with at least 16 species occurring in the reserve (Vieira 1999a). Feeding trials were conducted between October 1995 and May 1997 and involved 117 individual rodents belonging to eight of the most common species captured in forested areas of the PEI. These species were (mean adult weight \pm standard deviation and sample size between parenthesis): Oryzomys russatus $(91 \pm 9 \mathrm{~g}, \mathrm{~N}=66)$, Delomys dorsalis $(72 \pm 7 \mathrm{~g}$, $\mathrm{N}=4)$, Oligoryzomys nigripes $(29 \pm 4 \mathrm{~g}, \mathrm{~N}=5)$,
Nectomys squamipes $(253 \pm 34 \mathrm{~g}, \mathrm{~N}=15)$, Akodon serrensis $(45 \pm 6 \mathrm{~g}, \mathrm{~N}=9)$, Oecomys aff. concolor $(84 \pm 8 \mathrm{~g}, \mathrm{~N}=7)$, Wilfredomys pictipes (26 $\mathrm{g} \pm 5, \mathrm{~N}=7$ ), and Trinomys iheringi $(274 \pm 33 \mathrm{~g}, \mathrm{~N}=5)$. We kept the animals alive in small cages $(25 \times 15 \times 15 \mathrm{~cm})$ during the period of trials after which they were released at the place of capture. All cages housing rodents were also provided ad libitum with water, orange pieces, dog chow, banana pieces and sunflower seeds. Thus the animals would not have to obligatorily feed on the offered fruits. The rodents were held in captivity for two to five days.

Whole ripe fruits of 30 plant species (23 genera, 15 families) were offered to rodents (Table 1). Fruits were collected directly from the canopies or were recently fallen. For each plant species we measured minimum diameter of fruit and seed with calipers to the nearest 0.5 $\mathrm{mm}$. These values were used as an index of fruit and seed size. Whenever possible fruits were offered to at least three adult individuals (in individual cages) of each rodent species. Forty-eight hours after offering fruits we inspected the cages and recorded the fruit parts eaten (i.e. mesocarp, aril, or seed). We chose to inspect the cages after $48 \mathrm{~h}$ to give the animals time to get used to the cage and become hungry enough to search for food. Plant and rodent species were selected according to their availability at the time of study. We offered to the rodents fruits of every plant species that we could collect. In most cases we could determine seed predation due to missing or partially eaten seeds but sometimes the seeds were so tiny that we could not determine if they had been destroyed or passed intact through the digestive system of the rodents.

We analyzed the seed consumption by rodents for differences related to seed size with Fisher exact tests to compare number of plant species consumed in each seed size class. Seed sizes were divided for analysis into two categories : small (diameter equal or less than $10 \mathrm{~mm}$ ) and large (greater than $10 \mathrm{~mm}$ ). These classes are approximately equally represented in the group of fleshy-fruited flora offered to the rodents (about $42 \%$ of small and $52 \%$ of large seeds, $\mathrm{N}=30$ species). We performed statistical tests only for the rodent species to which more than ten plant species were offered. 
TABLE 1. - List of plant species in which fruits were offered to rodents. Numbers in parenthesis indicate seed diameter for each species (in millimeters). Also indicated are parts of the fruits that were eaten. $(+)$ denotes that the indicated fruit structure was consumed, $(-)$ denotes that it was not consumed, (n) denotes that the fruit does not have the indicated structure and (?) denotes that results were indeterminate, generally because seeds were minute and not readily found. Fruits were offered to at least three individuals of each species, when this was not possible, the number of individuals is indicated in superscript. Rodent species were placed in crescent order of body size (see text for mean body mass of each species) and their codes are as follows : WIPI = Wilfredomys pictipes, OLNI = Oligoryzomys nigripes, OECO = Oecomys aff. concolor, ORRU = Oryzomys russatus, NESQ = Nectomys squamipes, $\mathrm{DEDO}=$ Delomys dorsalis, AKSE $=$ Akodon serrensis, TRIH $=$ Trinomys iheringi . Fruit structure codes are as follows : $M=$ Mesocarp, $A=$ Aril, $S=$ Seed. $(a)=$ seed diameter was not measured ; $(b)=$ one entire infrutescence not eaten ; (c) = one of three individuals ate mesocarp and seed ; (d) = fruits were not opened by any species, seeds were eaten only when offered apart.

\begin{tabular}{|c|c|c|c|c|c|c|c|c|c|c|c|c|c|c|c|c|c|c|c|c|c|c|c|c|}
\hline \multirow[t]{3}{*}{ Plant family and species } & \multicolumn{23}{|c|}{ Rodent species } & \multirow[t]{3}{*}{ Obs. } \\
\hline & \multicolumn{3}{|c|}{ WIP } & \multicolumn{3}{|c|}{ OLNI } & \multicolumn{3}{|c|}{ AKSE } & \multicolumn{3}{|c|}{ DEDO } & \multicolumn{2}{|c|}{ OECO } & \multicolumn{3}{|c|}{ ORRU } & \multicolumn{3}{|c|}{ NESQ } & \multicolumn{3}{|c|}{ TRIH } & \\
\hline & M & $\mathrm{A}$ & $S$ & M & A & S & M & A & S & M & A & S 1 & M & A S & $S M$ & U A & $S$ & M & $A$ & S & M & A & S & \\
\hline \multicolumn{25}{|l|}{ Annonaceae } \\
\hline Guatteria australis (5.0) & & & & & & & & & & & & & & & + & $+n$ & $t^{2}$ & & & & + & $\mathrm{n}$ & +1 & \\
\hline \multicolumn{25}{|l|}{ Araceaea } \\
\hline Monstera adansonii (6.0) & & & & & & & & & & & & & & & & & & & & & - & $\mathrm{n}$ & $-^{*}$ & ${ }^{*}(\mathrm{~b})$ \\
\hline Arecaceae & & & & & & & & & & & & & & & & & & & & & & & & \\
\hline Euterpe edulis (11.0) & - & $\mathrm{n}$ & $-^{2}$ & + & $\mathrm{n}$ & - & + & $\mathrm{n}$ & - & + & $n$ & $t^{1}$ & + & $n-2$ & $z^{2}+$ & + & + & + & $\mathrm{n}$ & + & + & $\mathrm{n}$ & + & \\
\hline Geonoma pauciflora (6.0) & & & & + & $\mathrm{n}$ & $t^{2}$ & & & & + & $n$ & $t^{1}$ & & & + & + & + & + & $\mathrm{n}$ & + & + & $\mathrm{n}$ & + & \\
\hline Hippocraeaceae & & & & & & & & & & & & & & & & & & & & & & & & \\
\hline Salacia sp (15.0) & & & & & & & & & & & & & & & - & $-n$ & $-{ }^{*}$ & & & & & & & ${ }^{*}(\mathrm{c})$ \\
\hline Lauraceaea & & & & & & & & & & & & & & & & & & & & & & & & \\
\hline Cryptocaria moschata (15.0) & - & $\mathrm{n}$ & -1 & + & $\mathrm{n}$ & - & + & $\mathrm{n}$ & - & + & $\mathrm{n}$ & $t^{1}$ & + & $n+t^{2}$ & $t^{2}+$ & $+n$ & - & + & $\mathrm{n}$ & - & + & $\mathrm{n}$ & + & \\
\hline Loganiaceae & & & & & & & & & & & & & & & & & & & & & & & & \\
\hline Strychnos brasiliensis (11.0) & & & & & & & & & & & & & & & + & + & $--^{2}$ & + & $\mathrm{n}$ & + & & & & \\
\hline Moraceae & & & & & & & & & & & & & & & & & & & & & & & & \\
\hline Ficus sp (1.5) & & & & & & & & & & & & & & & + & $+n$ & ? & & & & & & & \\
\hline Myristicaceae & & & & & & & & & & & & & & & & & & & & & & & & \\
\hline Virola bicuhyba (15.0) & $\mathrm{n}$ & - & - & $\mathrm{n}$ & - & -1 & $n$ & + & $-^{2}$ & $n$ & - & $t^{1}$ & $n$ & $\begin{array}{llll}- & +1 & r & 0\end{array}$ & $+^{1} n$ & $n+$ & + & $\mathrm{n}$ & + & - & $\mathrm{n}$ & + & $t^{2}$ & \\
\hline Myrtaceae & & & & & & & & & & & & & & & & & & & & & & & & \\
\hline Campomanesia neriiflora (9.0) & & & & & & & & & & & & & & & & & & & & & + & $\mathrm{n}$ & $t^{1}$ & \\
\hline Eugenia melanogyna (21.0) & & & & & & & & & & & & & & & + & + & - & & & & & & & \\
\hline Eugenia oblongata (15.0) & & & & & & & & & & + & $\mathrm{n}$ & $t^{1}$ & & & & & & & & & + & $\mathrm{n}$ & $t^{1}$ & \\
\hline Eugenia riedeliana (12.0) & & & & & & & & & & & & & & & - & $-n$ & - & - & $\mathrm{n}$ & $t^{2}$ & - & $n$ & +1 & \\
\hline Eugenia stictosepala (16.0) & & & & + & $\mathrm{n}$ & $-^{2}$ & & & & & & & & & + & + & - & + & $n$ & + & & & & \\
\hline Eugenia sp1 (3.0) & - & $\mathrm{n}$ & -1 & + & $\mathrm{n}$ & $-^{2}$ & + & $\mathrm{n}$ & - & + & $\mathrm{n}$ & $t^{1}$ & - & $n-{ }^{2}$ & $z^{2}+$ & $+n$ & +1 & & & & + & $\mathrm{n}$ & $t^{1}$ & \\
\hline Eugenia sp2 (a) & + & $\mathrm{n}$ & $-^{2}$ & & & & & & & & & & & & & & & & & & - & $\mathrm{n}$ & +1 & \\
\hline Eugenia sp3 (a) & & & & - & $\mathrm{n}$ & -1 & & & & & & & + & $n-1$ & $-1+$ & + & $t^{2}$ & & & & & & & \\
\hline Eugenia sp4 (a) & & & & - & $n$ & -1 & & & & & & & + & $n-1$ & $-1+$ & + & $t^{2}$ & & & & & & & \\
\hline Gomidesia spectabilis (11.0) & - & $\mathrm{n}$ & $-^{2}$ & + & $n$ & $++^{1}$ & & & & + & $\mathrm{n}$ & $++^{1}$ & & & + & + & + & + & $\mathrm{n}$ & $t^{1}$ & + & $\mathrm{n}$ & $t^{1}$ & \\
\hline Marlierea obscura (7.0) & & & & & & & & & & & & & & & & $+n$ & +1 & & & & & & & \\
\hline Myrceugenia reitzii (8.0) & & & & & & & & & & & & & & & + & + & -1 & & & & + & $\mathrm{n}$ & $t^{1}$ & \\
\hline Nyctaginaceae & & & & & & & & & & & & & & & & & & & & & & & & \\
\hline Guapira opposita (6.0) & & & & & & & & & & & & & & & + & + & +1 & & & & & & & \\
\hline Quiinaceae & & & & & & & & & & & & & & & & & & & & & & & & \\
\hline Quina glaziovii (9.0) & & & & & & & & & & & & & & & + & $+n$ & +1 & & & & & & & \\
\hline Rubiaceae & & & & & & & & & & & & & & & & & & & & & & & & \\
\hline Coccocypselum sp. (1.5) & & & & & & & + & $\mathrm{n}$ & $t^{1}$ & & & & & & + & + & $7+$ & + & $\mathrm{n}$ & + & - & $\mathrm{n}$ & -1 & \\
\hline Posoqueria latifolia (12.0) & & & & & & & & & & & & & & & & & $t^{*}$ & - & $\mathrm{n}$ & $t^{*}$ & - & $n$ & $t^{*}$ & ${ }^{*}(\mathrm{~d})$ \\
\hline Psychotria suterella (3.0) & & & & + & $\mathrm{n}$ & $t^{1}$ & - & $\mathrm{n}$ & -1 & & & & & & + & + & +1 & + & $\mathrm{n}$ & $t^{1}$ & & & & \\
\hline Sapotaceae & & & & & & & & & & & & & & & & & & & & & & & & \\
\hline Chrysophyllum viride (5.0) & & & & + & $\mathrm{n}$ & $-^{2}$ & & & & & & & & & & & & & & & & & & \\
\hline Pouteria venosa $(1.0)$ & & & & & & & & & & & & & & & & & & & & & + & $\mathrm{n}$ & $t^{1}$ & \\
\hline Solanaceae & & & & & & & & & & & & & & & & & & & & & & & & \\
\hline Solanum inaequale $(1.0)$ & & & & & & & & & & & & & & & + & $+n$ & + & - & $\mathrm{n}$ & -1 & + & $\mathrm{n}$ & $?$ & \\
\hline Verbenaceae & & & & & & & & & & & & & & & & & & & & & & & & \\
\hline Citharexylum myrianthum (5.0) & & & & & & & & & & & & & & & + & + & +1 & & & & + & $\mathrm{n}$ & + & \\
\hline
\end{tabular}




\section{RESULTS AND DISCUSSION}

Rodent species differed in their patterns of fruit and seed consumption (Table 1). The animals fed on mesocarp of most fruits offered. Nevertheless, although we were not able to offer all fruits to all rodent species, seed size seemed to influence the patterns of seed consumption by the rodents to whom fruits were offered (Fig. 1). For the medium-sized $O$. russatus, there was a significant difference among plant species eaten or not eaten in different size classes $(\mathrm{P}<0.03, \mathrm{~N}=23)$. This relationship was not significant for the other two species with sufficient sample size for analysis, the large-sized Nectomys squamipes ( $\mathrm{P}>0.9$, $\mathrm{N}=11)$ and Trinomys iheringi $(\mathrm{P}>0.4, \mathrm{~N}=18)$.

Three groups can be recognized among the studied species. The first group is composed by the smallest species Alrodon serrensis, Oligoryzomys nigripes, Wilfredomys pictipes, and the medium sized Oecomys aff. concolor . This group fed mainly on pulp and sometimes on small seeds (< $10 \mathrm{~mm}$ diameter). Oryzomys russatus could be placed alone in another group. This medium-sized rodent fed on pulp and also on seeds up to about $15-\mathrm{mm}$ diameter. A third group, composed by Delomys dorsalis, Nectomys squamipes, and Trinomys iheringi, fed more equally on seeds of all sizes (Fig. 1 ; Table 1).

Adler (1995) provided detailed information on fruit and seed exploitation by Proechimys semispinosus (Echimyidae) in Central America. Guillotin (1982) provides information on diet and fruit consumption of Proechimys cuvieri and Oryzomys capito in French Guyana. For other Neotropical echimyids or murids from South America, however, such information is not available. The present study is admittedly descriptive and preliminary because the comparisons of seed consumption among species were restricted to only two size classes because we could not offer fruits of all plant species to all rodent species. Nonetheless, we here provide the first detailed information on the use of fruits and seeds by a rodent community of the Brazilian Atlantic Forest.

Wirminghaus and Perrin (1992) investigated the diet of five small mammals from African forests and reported that fruits are relatively common in the diet of three of them. The pre-

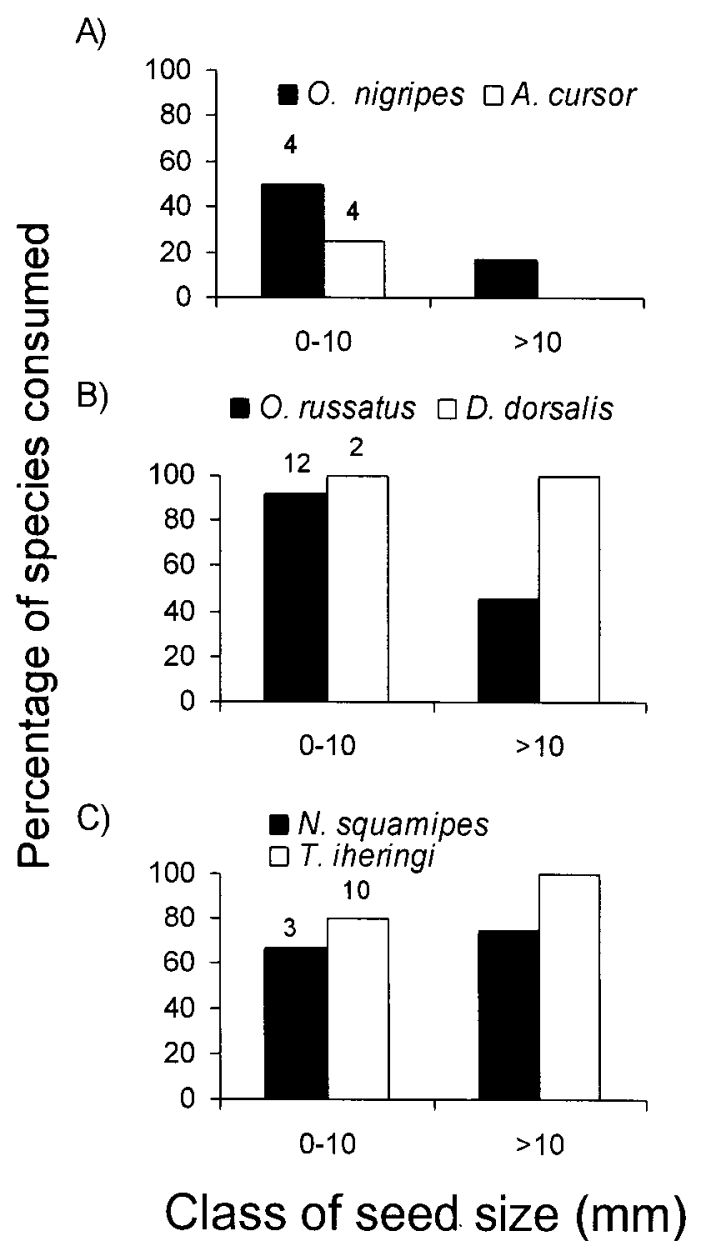

Fig. 1. - Percentage of seed consumption by rodents in relation to seed diameter. Rodent species were grouped in three size classes: A - small $(25-45 \mathrm{~g}), \mathrm{B}$ medium (70-100 g), and C - large (250-275 g). Numbers of plant species whose seeds were offered to each rodent species in each size class are indicated above bars.

sent study showed that all small forest rodents studied are able to feed on fruits and seed but those animals differ in their patterns of fruit and seed exploitation. Even species that feed on seeds of the same size present distinct ecological characteristics that may influence the way they could affect seed survival. The smallest rodents that we studied show marked differences in vertical habitat utilization. Akodon serrensis is basically terrestrial, Oryzomys nigripes is scansorial, and Wilfredomys pictipes and 
Oecomys aff. concolor are mainly arboreal (Vieira and Monteiro-Filho in press). Such differences might influence not only the fruit and seed selection by these rodents but also the probability of potential deposition of seeds on sites adequate for seed germination and seedling establishment. Studies conducted in a mixed ombrophilous forest with araucaria "pine" (Araucaria angustifolia) in southern Brazil have indicated that, at least Oryzomys nigripes, is able to defecate intact seeds and possibly act as seed disperser for Leandra spp (Melastomataceae) (Vieira and Paise, unp. data).

Guillotin (1982) reported that O. capito individuals from forests in French Guyana accepted $77 \%$ of fruits offered to captive animals $(\mathrm{N}=49$ species $)$. Our results indicated a similar pattern of fruit consumption for the congeneric $O$. russatus. For this medium-sized, cursorial rodent seeds larger than $15 \mathrm{~mm}$, such as those of Cryptocarya moschata, Eugenia melanogyna and E. stictosepala, remained intact after being manipulated. In another study conducted at the same study area Briani et al. (2001) used spool-and-line devices and found intact seeds of some medium to large-seeded species (Euterpe edulis, Cryptocaria moschata, Rheedia gardneriana) inside natural nests and also along the trails of $O$. russatus. This suggests that in natural conditions this species may move seeds from their primary deposition site without harming them. This behavior indicate that, besides being able to prey on small seeds, this rodent might act as secondary seed disperser of plant species with large-sized seeds.

The medium-sized Delomys dorsalis and the large Trinomys iheringi and Nectomys squamipes, all terrestrial, consumed both fruit and seed of most species regardless of their size. These rodents are probably the main seed predators in the rodent community of the BAF, especially T. iheringi and N. squamipes, and with Oryzomys russatus, which are widespread and abundant in the Atlantic forest (Vieira 1999a). Preliminary data suggests that $D$. dorsalis also is able to act as a disperser of small-seeded Melastomes (Vieira and Paise, unp. data). If T. iheringi and $N$. squamipes also scatterhoard seeds, as suggested for Proechumys semispinosus in Central America (Forget 1992), then they might be effective seed dispersers for some spe- cies, while also being predators of a wide variety of plants.

Our results showed that while all species studied feed on fruits, they differed in their patterns of seed exploitation, and that such interaction is associated with the relationship between rodent body size and seed size. The smallest rodent species exploited mainly small or medium-sized seeds, whereas larger rodent species are able to eat the whole range of seed size used in this study ( $1-51 \mathrm{~mm}$ diameter). For this range of seed size we predict a decrease in predation pressure as seed size increases. Such a prediction parallels the findings of Blate et al. (1998) who studied seed removal by rodents of 40 plant species in an Indonesian rainforest. The relationship between rodent size and seed size regarding predation probability is uncertain and may depend on the seed size range considered in the study (Hulme 1993). We do not know if size is the seed attribute that really matters for rodents or if it is another trait that covaries with it (e.g. seed coat thickness, deterrent substance, toxicity).

Community composition of small mammals in the Neotropics shows great spatial variation caused by different processes such as habitat complexity and heterogeneity, habitat fragmentation, edge effects, wildfires, selective logging, and others (Fonseca 1989 ; Stallings et al. 1990 ; Malcolm 1994, 1995 ; Vieira 1999a, $1999 b)$. These community differences exist even among areas located in the same vegetation type. Therefore one should consider local composition of species and species preference in order to evaluate the impact of small mammal communities on seed predation. This could enable more realistic comparisons and stronger inferences about general patterns.

\section{Acknowledgments}

We thank P.-M. Forget, G. Ganade, and an anonymous reviewer for helpful comments on earlier drafts of this paper and L. M. Fiuza for translation of the abstract to French. The Fundação para a Produção e Conservação Florestal do Estado de São Paulo kindly authorized the field work and provided logistical support at the Intervales State Park. This study was partially supported by doctoral scholarships from the Conselho Nacional de Pesquisa e Desenvolvimento Científico e Tecnológico (CNPq) to EMV and from the FAPESP to MAP and PI. 


\section{REFERENCES}

AdLeR, G.H., 1995. - Fruit and seed exploitation by central American spiny rats, Proechimys semispinosus. Stud. Neotrop. Fauna and Environ., 30 : 237-244.

Blate, G.M., D.R. Peart and D.M. Leighton, 1998. - Post-dispersal predation on isolated seeds : a comparative study of 40 tree species in a southeastern Asian rainforest. Oikos, 82 : 522-538.

BreWer, S.W. and M. RejMÁNeK, 1999. - Small rodents as significant dispersers of tree seeds in a Neotropical forest. J. Veg. Scien., 10 : 165-174.

Briani, D.C., E.M. VieIRA, and M.V. Vieira, 2001. Nest characteristics and selection of nesting sites by two Brazilian rodents. Acta Theriol., $46: 331-334$.

EMMONs, L.H. and F. FeER, 1997. - Neotropical rainforest mammals. A field guide. The University of Chicago Press, Chicago.

FonseCA, G.A.B., 1989. - Small mammal species diversity in Brazilian tropical primary and secondary forests of different sizes. Rev. Brasil. Zool., 6 : 381422.

Forget, P.M., 1991. - Scatterhoarding of Astrocaryum paramaca by Proechimys in French Guyana : comparison with Myoprocta exilis. Trop. Ecol., 32 : 155-167.

ForGET, P.M., 1992. - Seed removal and seed fate in Gustavia superba (Lecythidaceae). Biotropica, 24 : 408-414.

GLANZ, W.E., 1990. - Neotropical mammal densities : How unusual is the community on Barro Colorado Island, Panama? Pp. 287-313 in : Four Neotropical Rainforests. Ed. Gentry, Yale University Press, New Haven.

Guillotin, M., 1982. - Rythmes d'activité et régimes alimentaires de Proechimys cuvieri et d'Oryzomys capito velutinus (Rodentia) en forêt guyanaise. Revue d'Ecologie (Terre Vie), $36: 337-371$.

HallWaChS, W., 1986. - Agoutis (Dasyprocta punctata) : the inheritors of guapinol (Hymenaea courbaril: Leguminosa). Pp. 285-304 in: Frugivores and seed dispersal. Eds. Estrada and Fleming, Dr. W. Junk Publishers, Dordrecht.

Hoch, G.A. and G.H. AdLER, 1997. - Removal of black palm (Astrocaryum standleyanum) seeds by spiny rats (Proechimys semispinosus). J. Trop. Ecol., $13: 51-58$.

Howe, H.F. and J. SMalwood, 1982. - Ecology of seed dispersal. Ann. Rev. Ecol. Syst., 13 : 201-228.

Hulme, P. E., 1993. - Post-dispersal seed predation by small mammals. Symp. Zool. Soc. Lond., 65 : 269287.
JANZEN, D.H., 1970. - Herbivores and the number of tree species in tropical forests. Amer. Nat., 104 : 501-528.

Malcolm, J.R., 1994. - Edge effects in Central Amazonian forest fragments. Ecology, 75 : 2438-2445.

MalCOLM, J.R., 1995. - Forest structure and the abundance and diversity of Neotropical small mammals. Pp. 179-197 in : Forest canopies. Eds. Lowman and Nadkarni, Academic Press, London.

SancheZ-Cordero, V. and R. Martinez-Gallardo, 1998. - Post dispersal fruit and seed removal by forest-dwelling rodents in a lowland rainforest in Mexico. J. Trop. Ecol., 14 : 139-151.

Smythe, N., 1989. - Seed survival in the palm Astrocaryum standleyanum evidence for dependence upon its seed dispersers. Biotropica, 21 : 50-56.

Stallings, J.R., L.P.S. Pinto, L. Aguiar and E.L. SÁBATO, 1990. - A importância de distúrbios intermediários na manutenção da diversidade da fauna em uma floresta tropical. Pp. 43-58 in: Atas do Encontro de Ecologia Evolutiva. Eds. Martins, ACIESP, Rio Claro, SP.

Terborgh, J., 1986. - Community aspects of frugivory in tropical forests. Pp. 371-384 in: Frugivores and seed dispersal. Eds. Estrada and Fleming. Dr. W. Junk Publishers, Dordrecht.

Terborgh, E.J. Losos, M.P. Riley and M. BolanosRILEY, 1993. - Predation by vertebrates and invertebrates on the seeds of five canopy tree species of an Amazonian forest. Vegetatio, 107/108 : 375-386.

VieIRA, E.M., 1999a. - Estudo comparativo de comunidades de pequenos mamíferos em duas áreas de Mata Atlântica situadas a diferentes altitudes no Sudeste do Brasil. Doctorade thesis, Universidade Estadual de Campinas, Campinas, Brazil .

VieIRA, E.M., 1999b. - Small mammal communities and fire in the Brazilian Cerrado. J. Zool., Lond., 249: 75-81.

VIEIRA, E.M. and P. IZAR, 1999. - Interactions between aroids and arboreal mammals in the Brazilian Atlantic rainforest. Plant Ecology, 145 : 75-82.

Vieira, E.M. and E.L.A Monteiro-FilHo. - In press. Vertical stratification of small mammals in the Atlantic rain forest of south-eastern Brazil. J. Trop. Ecol.

Voss, R.S. and L.H. Emmons, 1996. - Mammalian diversity in Neotropical lowland rainforests : a preliminary assessment. Bull. Amer. Mus. Nat. Hist., $230: 1-115$.

Wirminghaus, J.O. and M.R. Perrin, 1992. - Diets of small mammals in a southern Aafrican temperate forest. Israel J. Zool., $38:$ 353-361. 